\title{
Analisis Multidrug Resistensi Terhadap Antibiotik Pada Salmonella typhi Dengan Teknik Multiplex PCR
}

\author{
ANDI EVI ERVIANI \\ Jurusan Biologi, Fakultas Matematika dan Ilmu Pengetahuan Alam, Universitas Hasanuddin \\ Jl. Perintis Kemerdekaan, Makassar 90516 \\ email: evierviani@gmail.com
}

\begin{abstract}
This research is about the analysis of resistance multidrug for antibiotic of Salmonella typhi with multiplex technique of PCR. This research purpose conducted to determine the presence of resistance multidrug for kloramfenikol and ampicillin of Salmonella typhi using multiplex technique of PCR. Testing of resistance multidrug performed using disc diffusion test and detection of resistance gene for kloramfenikol (cat $P$ ) and ampicillin (tem) with molecular technique using multiplex of PCR. Result of research indicate the suitability between resistance test using disc diffusion and detection resistance gene with multiplex of PCR, which is based on result of disc diffusion test and multiplex of PCR have occurred of resistance multidrug for kloramfenikol and ampicillin antibiotics, amount 10 patients $(33.3 \%)$, resistance of one antibiotics amount 10 patient $(33.3 \%)$ and non-resistance (sensitive) for both antibiotic amount 10 patient $(33.3 \%)$.
\end{abstract}

Keywords: Antibiotics, Multidrug, Resistance, Salmonella typhi

\section{PENDAHULUAN}

Lingkungan di sekitar manusia mengandung berbagai jenis unsur patogen, seperti bakteri, virus, fungi, protozoa dan parasit yang dapat menyebabkan infeksi pada manusia.. Salmonella typhi merupakan bakteri patogen yang dapat menimbulkan penyakit demam tifoid pada manusia, yang dapat dieksresikan melalui sekret saluran pencernaan, urine, dan tinja dalam waktu yang bervariasi (Kresno,2001; Lay,1994; Jawetz et al.,2001). S. typhi masuk ke dalam tubuh manusia melalui makanan atau minuman yang tercemar ke dalam lambung, kelenjar limfoid, usus halus kemudian masuk ke dalam peredaran darah (Kadang, 2000).

Sanitasi, higienitas dan vaksinasi yang dapat menurunkan tingkat insidensi penyakit cenderung masih sulit diterapkan di negara berkembang termasuk Indonesia, sehingga penggunaan antibiotik dinilai sebagai cara yang paling efektif. Antibiotik yang sering digunakan dalam terapi demam tifoid adalah klorampenikol, ampisilin, kotrimkszol, norfloksasin, neomisin, ciproflaksasin dan pefloksasin (Mirza et al., 2000).

Penggunaan antibiotik diketahui menyebabkan masalah baru yaitu munculnya resistensi terutama pada pemakaian antibiotik yang tidak prosedural dan tidak terkontrol (Mirza et al., 2000). Resistensi antibiotik pada demam tifoid seringkali dihubungkan dengan meningkatnya morbiditas dan mortalitas yang muncul. Dari beberapa hasil pengujian terhadap resistensi antibiotik membuktikan bahwa telah terjadi resistensi terhadap kloramphenikol, ampisilin, dan sulfonamid.

Teknik PCR dianggap suatu cara yang sederhana, praktis dan cepat untuk memperbanyak sekuen DNA spesifik yang diinginkan dengan ukuran tertentu dengan mekanisme perubahan suhu. Prinsip dasar dari metode ini adalah amplifikasi materi genetik yang terkandung dalam setiap organisme hidup. PCR dapat dilakukan dalam waktu kurang dari satu hari dan jutaan DNA dapat dihasilkan. Dalam penelitian ini, akan dilakukan analisa multidrug resistensi terhadap antibiotik kloramfenikol dan ampisilin pada penderita demam tifoid dengan menggunakan teknik multiplex PCR.

\section{METODE}

Kultur dan Identifikasi. Sampel darah dimasukkan ke dalam medium bile broth 1:10 kemudian diinkubasi pada temperatur $35-37^{\circ} \mathrm{C}$ 
selama 24 jam. Koloni yang tumbuh diinokulasi ke medium Salmonella Shigella pada temperatur $37^{\circ} \mathrm{C}$ selama 24 jam. Pertumbuhan koloni diamati, jika ada dilanjutkan pada TSI agar, diinkubasi $35-37^{\circ} \mathrm{C}$ selama 18-24 jam. Jika ada pertumbuhan dilanjutkan pada media SM, MR-VP, urea sitrat dan uji gula-gula, masing-masing diinkubasi $35-37^{0} \mathrm{C}$ selama $18-24$ jam.

Uji Disc Diffusion. Suspensi bakteri S.typhi dari kultur dilakukan pengenceran untuk mengetahui tingkat kekeruhan dengan menggunakan standar kekeruhan Mc Farland. Pada kepekaan yang sesuai dengan 0,5 standar Mc Farland ditanam pada permukaan agar Mueller Hilton-Agar dengan $\mathrm{pH}$ 7,2-7,4 dengan metode sebar. Kemudian paper disc yang mengandung antibiotik kloramfenikol dan antibiotik ampisilin diletakkan di permukaan agar, kemudian diinkubasikan semalam pada suhu $35^{\circ} \mathrm{C}$ selama $16-18$ jam. Zona hambatan yang terbentuk pada agar dan lebar zona tersebut dibandingkan dengan lebar zona hambat standar menurut Oxoid yang mengacu pada kriteria National Commitee for Clinical Laboratory Standard (NCCLS) dengan kategori resisten, intermediat dan sensitif. Kategori intermediat untuk kepentingan klinis dimasukkan dalam kategori resisten. Untuk kloramfenikol, kategori resisten ditunjukkan dengan diameter hambatan $\leq 12 \mathrm{~mm}$, intermediat $13-17 \mathrm{~mm}$, dan sensitif $\geq 18 \mathrm{~mm}$. Sedangkan untuk ampisilin, kategori resisten ditunjukkan dengan diameter hambatan $\leq 13 \mathrm{~mm}$, intermediat $14-16 \mathrm{~mm}$, dan sensitif $\geq 17 \mathrm{~mm}$.

Ekstraksi DNA. Sebanyak $900 \mu 1$ (buffer lisis) ditambahkan sampel sebanyak $100 \mu l$ atau sedimen sampel yang telah dipekatkan dengan menggunakan sentrifus kecepatan tinggi (12.000 rpm selama 10 menit) dan $40 \mu \mathrm{l}$ suspensi diatom ditambahkan ke dalam tabung. Campuran tersebut divortex dan diaduk dengan menggunakan gyrotary shaker dengan kecepatan $100 \mathrm{rpm}$ selama 10 menit. Kemudian divortex kembali dan disentrifus dalam mikrosentrifus ependorf pada kecepatan $12.000 \mathrm{rpm}$ selama 15 detik. Supernatan dipisahkan dari setiap vial dengan menggunakan pengisap yang terbuat dari pipet
Pasteur plastik tanpa balon udara dan dihubungkan dengan vacuum pump. Pencucian dilakukan sebanyak 2 kali dengan menggunakan $1 \mathrm{ml}$ buffer pencuci L2. $1 \mathrm{ml}$ buffer pencuci L2 ditambahkan ke dalam tabung dan divortex, sentrifus selama 15 detik dan supernatan diisap dengan menggunakan pipet. Pencucian dua kali dengan menggunakan etanol $70 \%$ dan 1 kali dengan 1 $\mathrm{ml}$ aseton. Aseton dipisahkan yang terdapat dalam supernatan dengan cara membuka penutup vial dan dipanaskan $56^{\circ} \mathrm{C}$ dalam water bath atau dengan menggunakan dry block heater. $60 \mathrm{ml}$ TE buffer elusi ditambahkan pada vial. Kemudian divortex secara merata sehingga sedimen dari suspensi tersebut larut. Vial diinkubasi dalam water bath selama 10 menit pada suhu $60{ }^{\circ} \mathrm{C}$. Sentrifus $12.000 \mathrm{rpm}$ selama 30 detik dan diambil secara hati-hati sekitar 40-50 $\mu$ l supernatan dan dimasukkan dalam vial yang baru. Buffer TE ditambahkan ulang $80 \mu \mathrm{k}$ ke dalam sedimen diatom dan divortex kembali sehingga sedimen akan larut dalam TE buffer elusi. Vial diinkubasi kembali pada water bath selama 10 menit pada suhu $56^{0}-60^{\circ} \mathrm{C}$. sentrifus $12.000 \mathrm{rpm}$ selama 30 detik dan diambil secara hati-hati sekitar 40-50 $\mu l$ supernatan dan dimasukkan dalam vial yang sama. Pada akhir prosedur Boom akan didapat sejumlah kecil diatom (sekitar $4 \mu$ suspensi diatom dalam $100 \mathrm{ml}$ TE buffer elusi). Hasil ekstraksi dapat disimpan pada suhu- $20^{\circ} \mathrm{C}$ atau suhu $-80^{\circ} \mathrm{C}$.

Proses Amplifikasi pada Mesin PCR untuk Deteksi gen cat $P$ dan Tem $F$. Amplifikasi PCR untuk pengujian resistensi diperlukan DNA mix untuk satu kali reaksi yang berisi dNTPs $2 \mu$, primer TEM Forward (Tem F) dan primer cat $\mathrm{P}$ Forward masingmasing 0,1 $\mu \mathrm{l}, 0,2 \mu \mathrm{l}$ Taq Polymerase, 10 kali PCR Buffer, dan aquades 17,6 $\mu$ l. Campuran reaksi ini dimasukkan dalam tabung $0,5 \mathrm{ml}$ dan ditambahkan 2,5 $\mu$ l ekstrak DNA Salmonella typhi hasil isolasi, dan 1 tabung diisi dengan 2,5 $\mu$ l aquadest steril sebagai kontrol negatif. Amplifikasi dengan menggunakan mesin PCR (DNA Termal Cycler) sebanyak 40 siklus dengan setiap siklus terdiri dari denaturasi $94^{\circ} \mathrm{C}$ selama 45 detik, annealing $57^{\circ} \mathrm{C}$ selama 60 detik, dan polimerisasi $72^{\circ} \mathrm{C}$ selama 60 
detik, setelah selesai 40 siklus kemudian diikuti dengan $72^{\circ} \mathrm{C}$ selama 1 malam. Hasil amplifikasi dapat disimpan pada suhu $-80^{\circ} \mathrm{C}$. Setelah amplifikasi, $8 \mu$ hasil amplifikasi PCR dan $2 \mu \mathrm{l}$ loading buffer dicampur dan dimasukkan ke dalam sumur gel agarose $2 \%$ yang sudah diberi ethidium bromida. Agar gel direndam pada wadah yang berisi buffer TBE, selanjutnya elektroforesis dijalankan selama 1 jam dengan tegangan konstan 100 volt. Setelah satu jam, elektroforesis dihentikan, gel diangkat untuk diamati di bawah sinar UV. Pada deteksi gen tem F (gen resisten terhadap ampisilin), dikatakan hasil positif jika terdapat pita DNA pada fragmen 291 pasangan basa, sedangkan untuk gen cat $\mathrm{P}$ (gen resisten terhadap kloramfenikol), dikatakan hasil positif jika terdapat pita DNA pada fragmen 436 pasangan basa.

Analisis Data. Data yang diperoleh dari hasil uji kultur, disc diffusion, dan multiplex PCR ditabulasi dan dianalisis

\section{HASIL}

Uji Resistensi Antibiotik Dengan Metode Disc Diffusion. Zona hambat yang terbentuk dari masing-masing disk antibiotik dibandingkan dengan lebar zona hambat standar menurut oxoid yang mengacu pada National Commitee for Clinical Laboratory Standars (NCLLS). Hasil pengukuran diameter hambatan dari antibiotik kloramfenikol dan ampisilin dapat dilihat pada tabel 1. Terjadi resistensi terhadap antibiotik kloramfenikol dan ampisilin. Di mana jumlah penderita demam tifoid yang resisten terhadap kedua antibiotik (Multi Drug Resisten) sebanyak 10 pasien $(33,3 \%)$.
Namun ada pula yang resisten hanya terhadap salah satu antibiotik, yaitu 5 pasien $(16,67 \%)$ yang resisten terhadap antibiotik kloramfenikol tetapi sensitif terhadap antibiotik ampisilin. Ditemukan 5 pasien $(16,67 \%)$ yang resisten terhadap antibiotik ampisilin, tetapi sensitif terhadap antibiotik kloramfenikol. Ada juga yang sensitif baik terhadap antibiotik kloramfenikol maupun antibiotik ampisilin, yaitu sebanyak 10 pasien $(33,3 \%)$.

Uji Resistensi Antibiotik Dengan Teknik Multiplex PCR. Pada uji PCR, resistensi terhadap kloramfenikol dideteksi dengan mengamplifikasi gen cat $P$, sedangkan resistensi terhadap ampisilin dideteksi dengan mengamplifikasi gen tem. Amplifikasi ini menggunakan primer forward untuk gen cat $P$ (5'-CC GTT GAT AT ATC CCAA TGG-3'), reverse (5'- CTG GTGA AACT CAC CC AGG G-3'), dan primer forward untuk gen tem (5'-GC TGATC TCA ACA GCG GTA AG3'), reverse (5'- C TGA CAA CGA GAG GACC-3') (Haque, et al., 2005).

\section{Pola Resistensi Antibiotik} Kloramfenikol dan Ampisilin Pada Penderita Demam Tifoid. Jumlah penderita demam tifoid yang resisten terhadap kloramfenikol berdasarkan uji PCR dan disc diffusion adalah 15 orang (50\%) (Tabel 3). Jumlah pasien yang tidak resisten (sensitif) juga 15 orang $(50 \%)$. Sedangkan untuk antibiotik ampisilin menunjukkan hasil yang sama. Di mana jumlah penderita demam tifoid yang resisten berdasarkan uji PCR dan Disc diffusion adalah 15 orang (50\%), dan jumlah penderita demam tifoid yang sensitif berjumlah 15 orang $(50 \%)$.

Tabel 1. Hasil pengukuran diameter hambatan terhadap antibiotik kloramfenikol dan ampisilin

\begin{tabular}{|c|c|c|c|c|c|c|c|c|c|}
\hline \multirow[t]{2}{*}{ No } & \multirow[t]{2}{*}{$\mathrm{RS}$} & \multirow[t]{2}{*}{ Nama } & \multirow[t]{2}{*}{$\begin{array}{l}\text { Umur } \\
\text { (tahun) }\end{array}$} & \multirow[t]{2}{*}{ JK } & \multirow[t]{2}{*}{$\begin{array}{l}\text { LD } \\
\text { (hari) }\end{array}$} & \multirow[t]{2}{*}{ Kultur } & \multicolumn{2}{|c|}{$\begin{array}{l}\text { Diameter zona hambatan } \\
\qquad(\mathrm{mm})\end{array}$} & \multirow[t]{2}{*}{ Kesimpulan } \\
\hline & & & & & & & Kloramfenikol & Ampisilin & \\
\hline 1 & WS & MT & 26 & $\mathrm{~L}$ & 5 & POS & $24(\mathrm{~S})$ & $25(\mathrm{~S})$ & $\mathrm{S}$ \\
\hline 2 & GW & JL & 38 & $\mathrm{P}$ & 7 & POS & $27(\mathrm{~S})$ & $24(\mathrm{~S})$ & S \\
\hline 3 & WS & $\mathrm{GH}$ & 45 & $\mathrm{~L}$ & 3 & POS & $21(\mathrm{~S})$ & $22(\mathrm{~S})$ & $\mathrm{S}$ \\
\hline 4 & DY & LI & 12 & $\mathrm{P}$ & 7 & POS & $23(\mathrm{~S})$ & $26(\mathrm{~S})$ & $\mathrm{S}$ \\
\hline 5 & UP & JU & 18 & $\mathrm{~L}$ & 4 & POS & $19(\mathrm{~S})$ & $28(\mathrm{~S})$ & $\mathrm{S}$ \\
\hline 6 & DY & GA & 29 & $\mathrm{~L}$ & 5 & POS & $20(\mathrm{~S})$ & $31(\mathrm{~S})$ & $\mathrm{S}$ \\
\hline
\end{tabular}




\begin{tabular}{cccccccccc}
\hline 7 & KS & YTM & 32 & P & 3 & POS & $25(\mathrm{~S})$ & $32(\mathrm{~S})$ & S \\
\hline 8 & GW & MK & 43 & L & 4 & POS & $23(\mathrm{~S})$ & $29(\mathrm{~S})$ & S \\
\hline 9 & KS & WS & 31 & L & 8 & POS & $22(\mathrm{~S})$ & $24(\mathrm{~S})$ & S \\
\hline 10 & WS & DM & 19 & P & 6 & POS & $30(\mathrm{~S})$ & $25(\mathrm{~S})$ & S \\
\hline 11 & DY & TK & 27 & L & 6 & POS & $10(\mathrm{R})$ & $22(\mathrm{~S})$ & SR \\
\hline 12 & KS & LS & 29 & P & 7 & POS & $11(\mathrm{R})$ & $20(\mathrm{~S})$ & SR \\
\hline 13 & DY & DUI & 50 & P & 4 & POS & $8(\mathrm{R})$ & $21(\mathrm{~S})$ & SR \\
\hline 14 & KS & FKL & 26 & L & 5 & POS & $9(\mathrm{R})$ & $28(\mathrm{~S})$ & SR \\
\hline 15 & WS & FKL & 16 & L & 4 & POS & $10(\mathrm{R})$ & $27(\mathrm{~S})$ & SR \\
\hline 16 & WS & HJ & 30 & P & 5 & POS & $28(\mathrm{~S})$ & $8(\mathrm{R})$ & SR \\
\hline 17 & KS & UT & 54 & L & 6 & POS & $24(\mathrm{~S})$ & $8(\mathrm{R})$ & SR \\
\hline 18 & GW & RI & 27 & L & 3 & POS & $23(\mathrm{~S})$ & $8(\mathrm{R})$ & SR \\
\hline 19 & KS & EB & 21 & P & 5 & POS & $25(\mathrm{~S})$ & $9(\mathrm{R})$ & SR \\
\hline 20 & DY & GG & 28 & L & 6 & POS & $27(\mathrm{~S})$ & $10(\mathrm{R})$ & SR \\
\hline 21 & UP & SY & 39 & L & 3 & POS & $8(\mathrm{R})$ & $11(\mathrm{R})$ & MDR \\
\hline 22 & WS & IW & 43 & P & 5 & POS & $11(\mathrm{R})$ & $13(\mathrm{R})$ & MDR \\
\hline 23 & GW & DW & 51 & L & 4 & POS & $12(\mathrm{R})$ & $12(\mathrm{R})$ & MDR \\
\hline 24 & DY & OB & 14 & L & 3 & POS & $14(\mathrm{R})$ & $10(\mathrm{R})$ & MDR \\
\hline 25 & WS & HH & 19 & P & 4 & POS & $8(\mathrm{R})$ & $10(\mathrm{R})$ & MDR \\
\hline 26 & KS & KW & 29 & P & 7 & POS & $10(\mathrm{R})$ & $9(\mathrm{R})$ & MDR \\
\hline 27 & DY & ART & 50 & P & 6 & POS & $8(\mathrm{R})$ & $8(\mathrm{R})$ & MDR \\
\hline 28 & WS & CG & 44 & L & 3 & POS & $9(\mathrm{R})$ & $8(\mathrm{R})$ & MDR \\
\hline 29 & KS & PIT & 34 & L & 6 & POS & $12(\mathrm{R})$ & $13(\mathrm{R})$ & MDR \\
\hline 30 & GW & JKE & 16 & L & 5 & POS & $8(\mathrm{R})$ & $12(\mathrm{R})$ & MDR \\
\hline Ketan & & & & & & &
\end{tabular}

\section{Keterangan}

WS : RS. Wahidin Sudirohusodo

DY : RS. Daya

GW : RS. Sungguhminasa, Gowa

KS : Puskesmas Kassi-Kassi, Makassar

$\mathrm{S} \quad$ : Sensitif terhadap antibiotik

$\mathrm{R} \quad$ : Resisten terhadap antibiotik

SR : Sensitif resisten (Resisten terhadap salah satu antibiotik)

MDR : Multi Drug Resisten (Resisten terhadap 2 antibiotik)

Tabel 2. Perbandingan hasil uji PCR dan uji disc diffusion

$\begin{array}{llllll}\text { No } & \text { RS } & \text { Nama } & \text { JK } & \text { Diameter zona hambatan }(\mathrm{mm}) U j i & \text { Uji PCR }\end{array}$

\section{Disc Diffusion}

\begin{tabular}{|c|c|c|c|c|c|c|c|c|}
\hline & & & & Kloramfenikol & Ampisilin & Cat $P$ & Tem F & \\
\hline 1 & WS & MT & $\mathrm{L}$ & $24(\mathrm{~S})$ & $25(\mathrm{~S})$ & Negatif & Negatif & $\mathrm{S}$ \\
\hline 2 & GW & JL & P & $27(\mathrm{~S})$ & $24(\mathrm{~S})$ & Negatif & Negatif & S \\
\hline 3 & WS & GH & $\mathrm{L}$ & $21(\mathrm{~S})$ & $22(\mathrm{~S})$ & Negatif & Negatif & $\mathrm{S}$ \\
\hline 4 & DY & LI & $\mathrm{P}$ & $23(\mathrm{~S})$ & $26(\mathrm{~S})$ & Negatif & Negatif & $\mathrm{S}$ \\
\hline 5 & UP & JU & $\mathrm{L}$ & $19(\mathrm{~S})$ & $28(\mathrm{~S})$ & Negatif & Negatif & $\mathrm{S}$ \\
\hline 6 & DY & GA & $\mathrm{L}$ & $20(\mathrm{~S})$ & $31(\mathrm{~S})$ & Negatif & Negatif & $\mathrm{S}$ \\
\hline 7 & KS & YTM & $\mathrm{P}$ & $25(\mathrm{~S})$ & $32(\mathrm{~S})$ & Negatif & Negatif & $\mathrm{S}$ \\
\hline 8 & GW & MK & $\mathrm{L}$ & $23(\mathrm{~S})$ & $29(\mathrm{~S})$ & Negatif & Negatif & $\mathrm{S}$ \\
\hline 9 & KS & WS & $\mathrm{L}$ & $22(\mathrm{~S})$ & $24(\mathrm{~S})$ & Negatif & Negatif & $\mathrm{S}$ \\
\hline 10 & WS & $\mathrm{DM}$ & $\mathrm{P}$ & $30(\mathrm{~S})$ & $25(\mathrm{~S})$ & Negatif & Negatif & $\mathrm{S}$ \\
\hline 11 & DY & TK & $\mathrm{L}$ & $10(\mathrm{R})$ & $22(\mathrm{~S})$ & Positif & Negatif & SR \\
\hline
\end{tabular}




\begin{tabular}{ccccccccc}
\hline 12 & KS & LS & P & $11(\mathrm{R})$ & $20(\mathrm{~S})$ & Positif & Negatif & SR \\
\hline 13 & DY & DUI & P & $8(\mathrm{R})$ & $21(\mathrm{~S})$ & Positif & Negatif & SR \\
\hline 14 & KS & FKL & L & $9(\mathrm{R})$ & $28(\mathrm{~S})$ & Positif & Negatif & SR \\
\hline 15 & WS & FKL & L & $10(\mathrm{R})$ & $27(\mathrm{~S})$ & Positif & Negatif & SR \\
\hline 16 & WS & HJ & P & $28(\mathrm{~S})$ & $8(\mathrm{R})$ & Negatif & Positif & SR \\
\hline 17 & KS & UT & L & $24(\mathrm{~S})$ & $8(\mathrm{R})$ & Negatif & Positif & SR \\
\hline 18 & GW & RI & L & $23(\mathrm{~S})$ & $8(\mathrm{R})$ & Negatif & Positif & SR \\
\hline 19 & KS & EB & P & $25(\mathrm{~S})$ & $9(\mathrm{R})$ & Negatif & Positif & SR \\
\hline 20 & DY & GG & L & $27(\mathrm{~S})$ & $10(\mathrm{R})$ & Negatif & Positif & SR \\
\hline 21 & UP & SY & L & $8(\mathrm{R})$ & $11(\mathrm{R})$ & Positif & Positif & MDR \\
\hline 22 & WS & IW & P & $11(\mathrm{R})$ & $13(\mathrm{R})$ & Positif & Positif & MDR \\
\hline 23 & GW & DW & L & $12(\mathrm{R})$ & $12(\mathrm{R})$ & Positif & Positif & MDR \\
\hline 24 & DY & OB & L & $14(\mathrm{R})$ & $10(\mathrm{R})$ & Positif & Positif & MDR \\
\hline 25 & WS & HH & P & $8(\mathrm{R})$ & $10(\mathrm{R})$ & Positif & Positif & MDR \\
\hline 26 & KS & KW & P & $10(\mathrm{R})$ & $9(\mathrm{R})$ & Positif & Positif & MDR \\
\hline 27 & DY & ART & P & $8(\mathrm{R})$ & $8(\mathrm{R})$ & Positif & Positif & MDR \\
\hline 28 & WS & CG & L & $9(\mathrm{R})$ & $8(\mathrm{R})$ & Positif & Positif & MDR \\
\hline 29 & KS & PIT & L & $12(\mathrm{R})$ & $13(\mathrm{R})$ & Positif & Positif & MDR \\
\hline 30 & GW & JKE & L & $8(\mathrm{R})$ & $12(\mathrm{R})$ & Positif & Positif & MDR \\
\hline
\end{tabular}

Tabel 3. Hubungan hasil tes sensitivitas antara metode disc diffusion terhadap sampel yang sensitive dan resisten dan teknik PCR Hasil Uji Disc diffusion

\begin{tabular}{|c|c|c|c|c|c|c|}
\hline \multirow{2}{*}{\multicolumn{3}{|c|}{ Hasil Uji }} & \multicolumn{4}{|c|}{ Disc diffusion } \\
\hline & & & \multicolumn{2}{|c|}{ Kloramfenikol } & \multicolumn{2}{|c|}{ Ampisilin } \\
\hline & & & $\begin{array}{c}\text { Positif } \\
\text { (Resisten) }\end{array}$ & $\begin{array}{c}\text { Negatif } \\
\text { (Sensitif) }\end{array}$ & $\begin{array}{c}\text { Positif } \\
\text { (Resisten) }\end{array}$ & $\begin{array}{c}\text { Negatif } \\
\text { (Sensitif) }\end{array}$ \\
\hline \multirow[t]{5}{*}{ PCR } & Kloramfenikol & Resisten & 15 & - & - & - \\
\hline & & Sensitif & - & 15 & - & - \\
\hline & Ampisilin & Resisten & - & - & 15 & - \\
\hline & & Sensitif & - & - & - & 15 \\
\hline & Total & & 15 & 15 & 15 & 15 \\
\hline
\end{tabular}

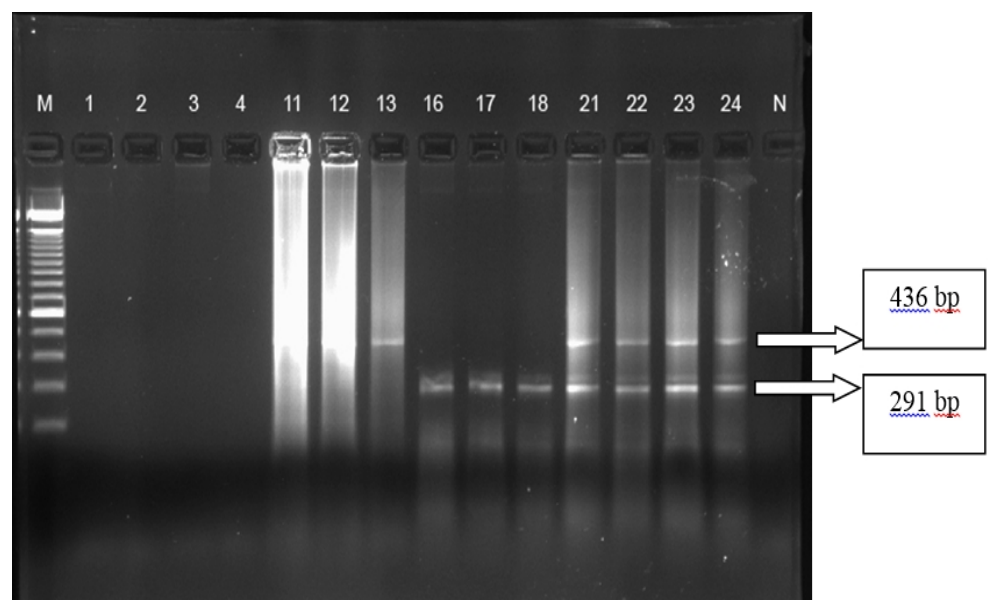

Gambar 1. Comb 1. Sumur 1:marker $100 \mathrm{bp}$, sumur 2-5: negatif gen cat $\mathrm{P}$ dan negatif gen tem F, sumur 6-8: positif gen cat $\mathrm{P}$, sumur 9-11: positif gen tem $\mathrm{F}$, sumur 12-15: positif gen cat $\mathrm{P}$ dan gen tem $\mathrm{F}$, sumur 16: kontrol negatif 


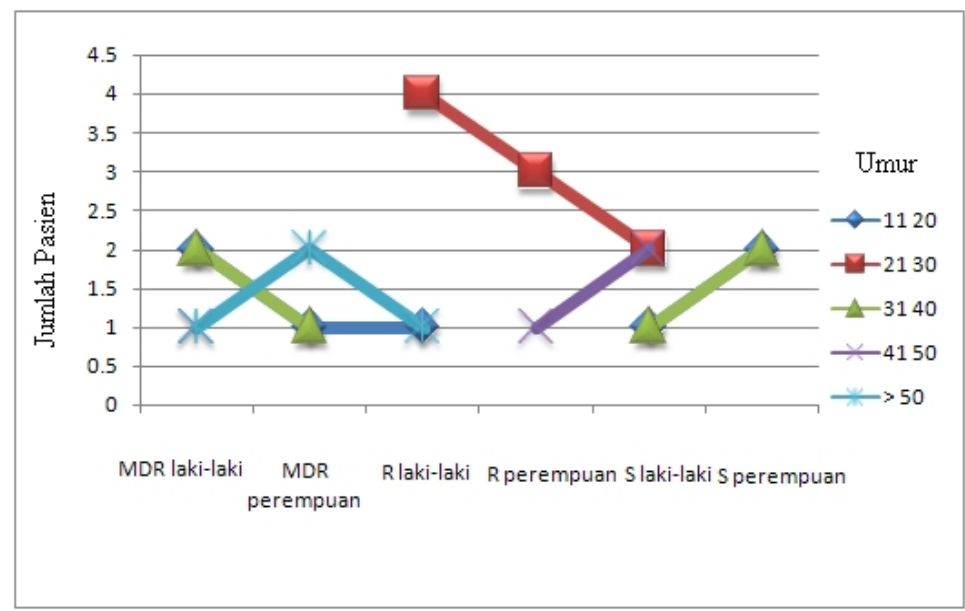

Gambar 2. Grafik pola resistensi antibiotik berdasarkan jenis kelamin dan kelompok umur

Tabel 4. Persentase penderita demam tifoid pada hasil kultur berdasarkan kelompok umur

Kelompok Umur

$11-20$ Tahun

$21-30$ Tahun

$31-40$ Tahun

$41-50$ Tahun
Kultur Positif

$$
7(23,3 \%)
$$

$10(33,3 \%)$

$5(16,7 \%)$

$6(20,0 \%)$

$$
2(6,7 \%)
$$

$30(100,0 \%)$

Tabel 5. Persentase penderita demam tifoid pada hasil kultur berdasarkan jenis kelamin

$\begin{array}{cc}\text { Jenis Kelamin } & \text { Kultur Positif } \\ \text { Laki-Laki } & 18(60,0 \%) \\ \text { Perempuan } & 12(40,0 \%) \\ \text { Jumlah Pasien (Orang) } & 30(100,0 \%)\end{array}$

Tabel 6. Persentase penderita demam tifoid pada hasil kultur berdasarkan lama demam

$\begin{array}{cc}\text { Lama Demam } & \text { Kultur Positif } \\ 1-6 \text { hari } & 25(83,3 \%) \\ 7-14 \text { hari } & 5(16,7 \%) \\ \text { Jumlah Pasien (Orang) } & 30(100,0 \%)\end{array}$

\section{PEMBAHASAN}

Uji Resistensi Antibiotik Dengan Metode Disc Diffusion dan Uji PCR. Dalam uji disc diffusion maupun dengan uji PCR (tabel 2) ditemukan jumlah penderita demam tifoid yang resisten terhadap kedua antibiotik sebanyak 10 pasien $(33,3 \%)$. Namun adapula yang resisten hanya terhadap salah satu antibiotik, yaitu 5 pasien $(16,67 \%)$ yang resisten terhadap antibiotik kloramfenikol tetapi sensitif terhadap antibiotik ampisilin. Ditemukan 5 pasien $(16,67 \%)$ yang resisten terhadap antibiotik ampisilin, tetapi sensitif terhadap antibiotik kloramfenikol. Ada juga yang sensitif baik terhadap antibiotik kloramfenikol maupun antibiotik ampisilin, yaitu sebanyak 10 pasien $(33,3 \%)$. Sesuai laporan Hadinegoro (1999), para klinisi di 
beberapa Negara mengamati adanya kasus demam tifoid yang berat disebabkan oleh strain $S$. typhi yang telah resisten terhadap antibiotik. Sehingga diperlukan pemilihan antibiotik yang tepat dan biaya yang tidak terlalu tinggi.

Metode disc diffusion digunakan untuk mengetahui resistensi dan sensitifitas bakteri terhadap penggunaan antibiotik. Kultur dan identifikasi bakteri $S$. typhi selama 4 hari, dilanjutkan dengan uji disc diffusion, yaitu suspensi bakteri S.typhi dari kultur dilakukan pengenceran kemudian ditanam pada permukaan Mueller Hilton Agar dengan metode sebar, selanjutnya paper disk yang mengandung antibiotik kloramfenikol dan ampisilin diletakkan di permukaan agar, kemudian diinkubasikan semalam (Brooks et al., 2005). Jadi total waktu yang dibutuhkan kurang lebih 1 minggu. Sedangkan metode PCR (multiplex PCR) selain mendeteksi keberadaan S. typhi juga bisa langsung mendeteksi adanya resistensi atau multidrug resistensi sampai ke tingkat gen dalam waktu kurang dari 10 jam. PCR lebih sensitif (100\%) dibandingkan dengan metode disc diffusion (Muladno, 2001). PCR dapat digunakan untuk mendeteksi adanya multidrug resistensi terhadap ampisilin dan kloramfenikol. Sehingga diketahui adanya $S$. typhi yang resisten terhadap kloramfemikol dan ampisilin karena adanya gen cat $P$ dan gen tem (gambar 1). Adanya fragmen DNA pada posisi $436 \mathrm{bp}$ menunjukkan bahwa terdapat gen cat $P$ termutasi dari Salmonella typhi yang resisten terhadap kloramfenikol. Sedangkan adanya fragmen DNA pada posisi $291 \mathrm{bp}$ menunjukkan bahwa terdapat gen tem termutasi dari Salmonella typhi yang resisten terhadap ampisilin.

\section{Pola Resistensi Antibiotik Pada Penderita Demam Tifoid Berdasarkan Kelompok Umur dan Jenis Kelamin.} Berdasarkan jenis kelamin (gambar 2), jumlah pasien yang multidrug resistensi lebih banyak ditemukan pada pasien berjenis kelamin lakilaki, yaitu 6 orang $(20,0 \%)$ dari pada perempuan yaitu 4 orang $(13,3 \%)$. Jumlah pasien yang resisten terhadap salah satu antibiotik juga ditemukan lebih banyak pada pasien berjenis kelamin laki-laki yaitu 6 orang $(40,0 \%)$ dari pada perempuan yaitu 4 orang (13,3\%). Jumlah pasien yang sensitif terhadap 2 antibiotik juga ditemukan lebih banyak pada pasien berjenis kelamin laki-laki yaitu 6 orang $(40,0 \%)$ dari pada perempuan yaitu 4 orang $(13,3 \%)$. Berdasarkan jenis kelamin, jumlah pasien yang multidrug resistensi, resisten, dan sensitif lebih banyak ditemukan pada pasien berjenis kelamin laki-laki. Sedangkan berdasarkan kelompok umur, pasien yang multidrug resistensi lebih banyak ditemukan pada kelompok umur antara 11-20 tahun dan 41-50 tahun, yaitu masing-masing 3 orang $(10,0 \%)$. Jumlah pasien yang resisten terhadap salah satu antibiotik lebih banyak ditemukan pada kelompok umur antara 21-30 tahun yaitu 7 orang $(23,3 \%)$. Jumlah pasien yang sensitif terhadap 2 antibiotik lebih banyak ditemukan pada kelompok umur antara 11-20 tahun dan 31-40 tahun, yaitu masing-masing 3 orang $(10,0 \%)$. Hal tersebut sesuai dengan pendapat Kadang (2003), bahwa demam tifoid dapat ditemukan pada semua kelompok umur, dan ditemukan lebih banyak pada laki-laki dibanding perempuan dengan rasio 2-3:1. Namun demikian, menurut B.Senthilkumar et al., (1995), wanita lebih bersifat carier dibandingkan pria dengan rasio 3:1.

Berdasarkan lama demam, penderita demam tifoid lebih banyak dijumpai pada lama demam 1-6 hari atau pada minggu pertama. Hal tersebut berarti hasil positif didapatkan pada minggu pertama berlangsungnya penyakit, yang disebabkan karena minggu pertama merupakan fase bakterimia dan septikimia yang berat. Pada fase tersebut, jumlah bakteri $S$. typhi yang berada dalam darah adalah besar, sehingga persentase kultur darah pada rentang demam di atas dapat mencapai $100 \%$ (Stratford, 1997).

Gejala demam tifoid yang timbul bervariasi. Dalam minggu pertama, gejala dan keluhan serupa dengan penyakit infeksi akut pada umumnya. Yaitu, demam, nyeri kepala, pusing, nyeri otot, anoreksia, mual, muntah, obstipasi atau diare, perasaan tidak enak di perut, batuk dan epistaksis. Pada pemeriksaan fisik hanya didapatkan peningkatan suhu badan. Dalam minggu kedua, gejala-gejala 
menjadi lebih jelas. Berupa demam, bradikardi relatif, lidah tifoid (kotor di tengah, tepi dan ujung merah), hepatomegali, splenomegali, meteorismus, gangguan kesadaran berupa samnolen sampai koma (Mansjoer, dkk., 2001).

Dalam pengujian metode kultur, dapat dipengaruhi oleh beberapa faktor. Diantaranya, penggunaan antibitok oleh penderita sebelum pemeriksaan, kurangnya volume darah yang digunakan untuk kultur, karakteristik intraselular $S$. typhi dan jenis media yang digunakan untuk kultur (Haque, et al., 1999).

Multi Drug Resistensi (MDR) Salmonella typhi Terhadap Antibiotik Ampisilin dan Kloramfenikol. Dari hasil pengujian terhadap resistensi antibiotik, baik menggunakan uji disc diffusion maupun uji PCR menunjukkan bahwa telah terjadi multidrug resistensi terhadap antibiotik ampisilin dan kloramfenikol. Diketahui, dalam berbagai pengobatan terhadap penyakit, ampisilin paling sering digunakan. Resistensi terhadap ampisilin sebagai salah satu antibotik yang termasuk dalam golongan penisilin ditentukan oleh produksi enzim perusak cincin penisilin yang dihasilkan organisme $(\beta-$ laktamase). Beta laktamase membuka cincin $\beta$-laktam penisilin dan sefalosporin $\beta$-laktam dan meniadakan aktivitas antimikrobianya. Ada satu kelompok $\beta$-laktamase yang kadangkadang ditemukan dalam spesies gram negatif misalnya Klebsiella pneumoniae dan E. coli. Enzim tersebut dikenal dengan Extended Spectrum $\beta$-laktamase (ESBL), yang mempunyai kemampuan tambahan kepada bakteri untuk menghidrolisa cincin $\beta$-laktam sefotaksim, seftasidim atau astreonam (Jawetz et al., 2001).

Di samping bakteri Klebsiella pneumoniae dan E.coli yang menghasilkan enzim ini, di beberapa negara telah dilaporkan juga bahwa bakteri gram negatif termasuk Enterobacter, Salmonella, Proteus, Citrobacter spp, Morganella morganii, Shigela dysenterica dan Pseudomonas aeruginosa menghasilkan ESBL. Pada Salmonella ditemukan beberapa macam ESBL yaitu enzim tem, sulfhydryl variabel (SHV),
PER, oxacilin OXA dan CTX-M (Kruger et al., 2004). Modifikasi biokimia antobiotik oleh enzim bakteri merupakan suatu masalah yang sangat serius dalam pengobatan antobiotik dan kemoterapi. Jawetz et al., (2001) menyebutkan bahwa semua obat $\beta$-laktam menghambat sintesis dinding sel bakteri dan oleh karena itu, aktif melawan pertumbuhan bakteri. Langkah awal dari aksi obat berupa ikatan obat pada reseptor sel. Setelah obat $\beta$-laktam melekat pada satu atau beberapa reseptor, reaksi transpeptidase dihambat dan sintesis peptidoglikan dihentikan. Langkah selanjutnya meliputi perpindahan atau inaktivasi inhibitor enzim otolitik pada dinding sel. Aktivasi enzim litik ini menimbulkan lisis jika lingkingan isotonik.

Ada dua tipe mekanisme resistensi untuk golongan penisilin. Satu mekanisme karena ketiadaan beberapa reseptor penisilin dan terjadi sebagai hasil mutasi kromosom. Kedua adalah kegagalan obat $\beta$-laktamase untuk mengaktivasi enzim otolitik pada dinding sel. Sebagai hasilnya, organisme dihambat tapi tidak dibunuh. Sifat toleransi ini telah diamati secara khusus pada Stafilokokus dan Streptokokus tertentu. Kloramfenikol sebagai antibiotik yang juga digunakan dalam penelitian ini, merupakan penghambat yang kuat terhadap sintesis protein pada mikroorganisme. Obat tersebut memblokir ikatan asam amino pada rantai peptida yang mulai timbul pada unit 50S ribosom dengan mengganggu kerja peptidyl transferase. Kloramfenikol bersifat bakteriostatik dan bakteri dapat tumbuh kembali jika pengaruh obat dihilangkan. Mikroorganisme resisten terhadap kloramfenikol karena menghasilkan enzim kloramfenikol acetyltranferase yang merusak aktivitas obat. Produksi enzim ini biasanya berada di bawah kontrol plasmid. (Jawetz et al., 2001).

Setelah kloramfenikol bertahan sekitar 25 tahun, dilaporkan oleh beberapa peneliti di berbagai negara adanya strain Salmonella typhi yang resisten terhadap kloramfenikol. Peneliti India melaporkan adanya kasus demam tifoid yang resisten terhadap kloramfenikol pada tahun 1970, sedangkan di Mexico pertama kali dilaporkan pada tahun 
1972 (Hadinegoro, 1999). Resistensi tersebut ternyata diikuti oleh adanya resistensi Salmonella typhi terhadap obat-obat lain yang biasa dipergunakan untuk mengobati demam tifoid. Pada bulan Juni 1988, dilaporkan bahwa telah terjadi resistensi terhadap kloramfenikol, ampisilin, trimethoprim, sulfamethoxazole di Mesir (Mikhail et al., 1989). Di negara berkembang, antibiotik yang tersedia untuk pengobatan demam tifoid adalah ampisilin, kloramfenikol, dan kotrimoksazol. Olarte dan Galindo melaporkan pertama kali adanya strain Salmonella typhi yang resisten terhadap ampisilin dan kloramfenikol di Mexico tahun 1973 (Hadinegoro, 1999).

Pada saat itu kotrimoksazol baru ditemukan sebagai pengganti kloramfenikol untuk mengobati demam tifoid meskipun kotrimoksazol cepat menjadi resisten. Pada perkembangan resistensi Salmonella typhi selanjutnya, beberapa negara melaporkan adanya strain Salmonella typhi yang telah resisten terhadap dua atau lebih golongan antibiotik utama untuk pengobatan demam tifoid yaitu kloramfenikol, ampisilin, amoksilin, dan kotrimoksazol (multi-drug resistant $=$ MDR Salmonella typhi) (Bhutta et al., 1994: Bhutta, 1997: Mirza, 1995: Memon et al., 1998).Pada tahun 1984 di Thailand dilaporkan adanya MDR pada demam tifoid anak, selanjutnya diikuti oleh negara lain (Mirza, 1995).

Terdapat 4 jalur mekanisme resistensi antibiotik, yaitu penurunan permeabilitas terhadap antibiotik, adanya proses enzimatik, modifikasi letak reseptor obat, dan peningkatan sintesis metabolit antagonis terhadap antibiotik.

Sampai saat ini baru diketahui empat faktor tersebut di atas yang dapat memutuskan kerja antibiotik, yang selanjutnya dapat menyebabkan resistensi masih terdapat faktor fisiologi dari mikroorganisme, tetapi hanya sedikit berpengaruh yaitu replikasi genetik sel (transcription, translocation) (Corcoran et al., 1992).

\section{KESIMPULAN}

1. Teknik Multiplex PCR secara umum mampu mendeteksi adanya multidrug resistensi pada penderita demam tifoid dengan menggunakan primer spesifik gen cat $P$ pada bands 436 bps terhadap kloramfenikol, dan primer spesifik gen tem pada bands 291 bps untuk deteksi resistensi terhadap ampisilin.

2. Terdapat Salmonella typhi yang multidrug resistensi terhadap antibiotik kloramfenikol dan ampisilin, sebanyak 10 sampel $(33,3$ $\%$ ). Resisten terhadap antibiotik kloramfenikol tetapi sensitif terhadap ampisilin sebanyak 5 sampel $(16,67 \%)$. Resisten terhadap antibiotik ampisiln tetapi sensitif terhadap kloramfenikol sebanyak 5 sampel (16,67\%). Tidak reisten (sensitif) terhadap kedua antibiotik sebanyak 10 sampel $(33,3 \%)$. Hal ini berdasarkan hasil dari dua uji, yaitu disc diffusion dan multiplex PCR.

3. Berdasarkan jenis kelamin, jumlah pasien yang multidrug resistensi, resisten, dan sensitif lebih banyak ditemukan pada pasien berjenis kelamin laki-laki dari pada perempuan.

4. Berdasarkan hasil kedua uji yang dilakukan menunjukkan diperolehnya sensitivitas dan spesivisitas yang sama terhadap antibiotik kloramfenikol dan ampisilin pada sampel darah.

Perlu dilakukan penelitian lebih lanjut mengenai resistensi antibiotik terhadap $S$. typhi, khususnya tentang Multi Drug Resistensi (MDR). Sedangkan untuk diagnostik resisten kloramfenikol dan ampisilin disarankan menggunakan teknik multiplex PCR agar tindakan pengobatan pada penderita demam tifoid cepat dilakukan.

\section{DAFTAR PUSTAKA}

Bhutta ZA, Khan IA dan Molla AM. 1994. Therapy of multidrug-resistant typhoid fever with oral cefixime vs. intravenous ceftriaxone. Pediatr Infect Dis J. vol 13: 990-994.

Bhutta ZA. 1997. MDR Typhoid: a potential algorithmic approach to diagnosis and management. Makalah disajikan pada Third Asia-Pacific Symposium on Typhoid Fever and Other Salmonellosis, Bali, 11 Desember. 
Brooks GF, Butel SJ, Morse, Stephan A. 2005. Mikrobiologi Kedokteran. Penerjemah dan Editor, Bagian Mikrobiologi Fakultas Kedokteran Universitas Airlangga, Salemba. Jakarta: Medika.

Hadinegoro SR. 2007. Masalah Multi Drug Resistance pada Demam Tifoid Anak. www.kalbe.co.id. Diakses 3 Juli 2007.

Haque A, Abdul H, Yasra S, Aamir A, Saira B, Ayesha T, and Mushkoor M. 2005. Identification of Drug Resistance Genes in Clinical Isolates of Salmonella typhi for Development of Diagnostic Multiplex PCR. Pak. Med. SCI.J. vol 21 (4), 402407.

Jawetz ZE, Joseph MEAA, Delberg. 2001. Mikrobiologi Kedokteran. Terjemahan oleh Eddy Mudihardi, dkk. Bagian Mikrobiologi Fak. Kedokteran Universitas Airlangga. Jakarta: Salemba Medika.

Kadang KJ. 2000. Pengenalan Dini Demam Tifoid. Makalah Temu Muka dan Konsultasi Metode Tepat Mengatasi Demam untuk Pengenalan Dini Demam Berdarah dan Tifoid. Bekasi: Klinik Anakku.

Kresno BS. 2001. Imunologi: Diagnosis dan Prosedur laboratorium Edisi IV. Jakarta: Fakultas Kedokteran, Universitas Indonesia.

Lay BW. 1994. Analisis Mikroba di Laboratorium. Jakarta: PT. Raja Grafindo Persada.

Mansjoer A, Triyanti K, Savitri R., Wardhani WI, Setiowulan W. 2001. Kapita Selekta Kedokteran. Jakarta: Media Aesculapius Fakultas Kedokteran Universitas Indonesia

Memon IA, Billoo AG, and Memon HI. 1998. Cefixime: An oral option for the treatment of multidrug-resistant enteric fever in children. South Med J. vol 90: 1204-7

Mirza SH. 1995. The Prevalence and Clinical Features of Multi-Drug Resistant Salmonella typhi Infections in Baluchistan, Pakistan. Ann Trop Med and Parasitol. vol 1 (89): 513-519.

Mirza S, Kariuki S, Mamun KZ, Beeching NJ. and Hart CA. 2000. Analiysis of Plasmid and Cromosomal DNA of MultidrugResistant Salmonella enterica Serovar Typhi from Asia. Journal of Clinical Microbiology. vol 38 (4): 1449-1452.

Muladno. 2001. Dasar-Dasar Teknik DNA dan Beberapa Aplikasinya. Bogor: Balai Penelitian dan Pengembangan Zoologi, Pusat Penelitian dan Pengembangan Biologi LIPI.

Myrvik QN, Russel S, dan Weiser. 1998. Fundamental of Medical Bacteriology and Mycology. Philadelphia: Lea and Febiger.

Naim R. 2002. Cara Kerja dan Mekanisme Resistensi Antibiotik. Harian Kompas. Diakses 20 februari 2008.

Olarte J and Emma G. 1973. Salmonella typhi Resistant to Chloramphenicol, Ampicilin, and Other Antimicrobial Agents: Strain Isolated during an Extensive Typhiod Fever Epidemic in Mexico. Antimicrob. Agents Chemotherapy J. vol 4: 597-601.

Parkhill J and Dougan G. 1989. Complete Genom Sequence of a Multiple Drug Resistant Salmonella enterica Serovar Typhi CT 18. Cambridge: Cambridge University Press.

Shanahan MA, Philippa, Mary VJ, Christoper JT and Sabastian GB. 1998. Molecular Analysis of and Identification of Antibiotic Resistance Genes in Clinical Isolates of Salmonella typhi from India. Clinical Microbiology J. vol 36(6): 1595. 